\title{
RELIGION: A NEW STRUGGLE FOR AFRICAN IDENTITY
}

\author{
John Sodiq Sanni
}

Department of Philosophy, Stellenbosch University

sodjohnsan@gmail.com

\section{ABSTRACT}

Looking at most African countries, one realises that the social imaginaries which make us who we are, continue to be an issue in every society. It is even more rampant when we think of the role religion plays in determining who we are, what we believe and how we should act and react. This article seeks to look at the nature of religion and how religion over the years played a significant role in African identity. This article proposes that African identity has been endangered by religion; that there is a need to rethink our conceptualisation of religion and to move away from the understanding of religion as the basis of identity. This is because our shared lives should and must be the basis of identity. In other words, imported religions have their own origin and this origin cannot be disassociated from the belief inherent in the religions. There is a need to free the mind of its conditionings that give priority to religion and may therefore serve to exclude other sources of identity derived from collective histories and collective experiences. The illusion which religion plunges us into is often the reason for the problems of identity which most African societies struggle with today. An awareness of this illusion and a new understanding of identity as derived from a shared African experience, will go a long way in resolving the problem of identity in Africa.

Keywords: Identity; Matrix; awareness; African; devalue; religion.

\section{INTRODUCTION}

Sometimes, when musing about life from the viewpoint of religion, one could wish to have been God - contemplating about how to have made things better. One of the many good things that come to mind, is to have made people appreciate each other

\section{UNISA}


and learn to see their similarities more than their socially constructed differences, especially those of religious affiliations, cultural or ethnic identities. Given our experience of violence, none of us would mind a deterministic configuration of humanity that is at unity with itself; at least peace would be assured. When you look at an individual, you are looking at someone who carries within him/herself a set of different signals of identity. When, for example, someone who knows West Africa asks me, "What is your name?" and I say, "I am John Sodiq Sanni”, a quizzical look appears on the face of my questioner. Those who are brave enough go on to ask, "What sort of combination is that, and where are you from?" I am sure you will also be puzzled and you cannot wait to reach the part where I answer this question - that is if I respond to it at all. The tangle of names signifies the diverse origin of my parents. My father was a Muslim and my mother a Christian.

Nonetheless, the crux of the issue is not only about names and how names point to a particular culture, but also how identities in the cultural hermeneutical underpinnings of names have been displaced by religious identities. African identity has become not so much about ethnic background but also about religious viewpoints; and I believe people in Africa may give the latter more significance than the former. The problem is that recent events in several African states have given a greater urgency to the place of religion in determining identity. Circumstances have valorised religious affiliations so that we think of a person in terms of religion and, as a result, that person thinks of him/herself in terms of religion. Our subjectivities are constructed not by what we think but how society has constructed how we should think; religion plays a holistic role in determining a person's understanding of his/ her origin and purpose.

Daniel Dennett (2006) rightly observes "that one of the most difficult tasks is finding the right questions to ask and the right order to ask them in. You have to figure out not only what you don't know, but what you need to know and don't need to know, and what you need to know in order to figure out what you need to know, and so forth" (Dennett 2006: 19). Our apparently unending quest to provide answers to the unknown has often been the justification for religion. This is the case because of the increase of religious leaders who often claim to have access to some divine revelations, purported to be an indisputable answer to the eternal question which troubles human beings.

The aim of this article is to differentiate between "identity as origin" and "identity as religion" and to prioritise the wider commonality that is inherent in identity as origin. I will also consider the need to free the mind of its conditioning that gives priority to religion and may therefore serve to exclude other sources of identity derived from collective histories and collective experiences. This implies that religion is not a collective experience as it is sometimes claimed to be. A prejudiced humanist may accuse religion of directing our attention to a transcendental teleology and in the process distracting us from our contingent reality. If one is to argue that the 
nature of reality is similar to that of identity, religion erodes identity. It is, however, impossible to theorise contemporary Africa and ignore the presence and influence of imported religions. By imported religion, I mean religions which are not uniquely African. Put differently, imported religions are those that infiltrated African societies through their interactions with other continents. Africa is multicultural and many of the sites of that multiculturalism have been constructed by both imported and indigenous religions.

A theoretical approach as to how we can resist imported religions' ${ }^{1}$ oversimplification of African identity is provided by revisiting Charles Taylor's notion of "multiculturalism and the politics of recognition". I will argue that there is a need to rethink the significance of religious diversity and an ontology that recognises the Other as part of Oneself. This very deep African notion which one finds in the

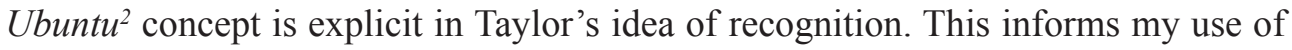
Taylor's postulations in this article. For Taylor, the politics of recognition proceeds from the proposition of an ontological ethical notion of the Other as a relational identity. I shall first offer definitions of important concepts.

\section{CONCEPTUAL FRAMEWORK}

Beginning with religion, amidst the different definitions, this paper appropriates the definition proposed by Monica Toft's account that talks about "belief in supernatural being or beings"; belief in a transcendent reality; distinction between the sacred and the profane; and a code of conduct for a temporal community that shares a world view (see Toft 2011: 115). Toft's definition of religion has a holistic dimension to it which is similar to the understanding of African traditional religion (ATR). The understanding of ATR here is '.. the indigenous religious beliefs and practices of the Africans' (Awolalu 1976: 1). Religion becomes the convergence point for other multiple perspectives which all seem to proceed from religion or seem to have their basis in religion. Olusegun Oladipo (1998), makes the convergence more explicit when he argues that religion is not only belief in a metaphysical being, but also a disposition towards that which one believes in.

Does religion also encompass identity or does it create identity? If one considers the fact that self-identity is largely based on community or a belonging, this identity cannot be isolated or entirely separated from this belonging. If this is the case, it will be plausible to argue that religion is identity, as it gives an individual a sense of belonging. It is, however, not as straightforward at it appears. A definition of identity

1 The phrase 'imported religion' is used to designate religions which came with colonialism and the Arabian trade. In order to avoid overgeneralisation, I refer to Christianity and Islam.

2 The Ubuntu concept is largely based on the idea that the one only exists because of the existence of Others. To ignore the existence of other people is to automatically deny one's existence (see Ramose 1998). 
might help unpack the puzzle that is implicit in the understanding of religion and its relation to identity. Identity, as presented by scholars like Taylor, is two dimensional: collective and personal.

Personal identity may be defined as the capability of conscious subjects to remain identical with themselves, despite changes that affect the structure of their personality. It is the unity and continuity of self-consciousness. Persons as conscious subjects are repeatedly faced with situations that challenge the existing structure of their consciousness - in other words, which contradict the way they feel, the way they think, the way they act. They can meet those situations and cope with the experience they involve only by reconstructing their personality or acquiring a new self, as we say. (Taylor 1994: 134 -135)

The collective dimension plays a significant role in enacting and authenticating the personal identity. It is important to also add that the response to the question of identity is also determined by context. Thus it has a local and international dimension which influences response. This will be further explored during the course of this paper. "Personal identity, as also collective identity, is a normative concept, not just descriptive. It is not used merely to describe a state of affairs, but to express an ideal to be striven for, a value to be embodied. For that reason, we can speak of a 'loss of identity', an 'identity crisis', of [sic] a 'weak identity' and so on" (Davis 1994: 135). African understanding of identity leaves very little room for personal autonomy, as one is only a person in so far as the person follows the moral dictates of the society (Okolo 1998: 213). In other words, an individual is only said to find himself within a society. In isolation, he is said not to exist. As opposed to an individual essence, there is an emphasis on collective significance in the African comprehension of identity.

\section{IS IDENTITY RELIGIOUS?}

At the beginning of this article, I asked how religion shapes or impacts our identity, especially in an African context where identity and religion are often implicated in one another. What does one make of religion in relation to identity? Is it possible to delineate cultural identity without explicit reference to religion? These questions, among many others, show the complex nature of religion as identity and culture as identity in relation to a person. These questions connect culture and identity because it is only from cultural relations that identity is realised.

As much as it can be argued that culture and religion can be separated - a point which will be argued as this article unfolds - it is important to note that most African "creation narratives" always have a religios dimension to them, which is intrinsically connected to cultural habits and actions. African traditional cultures often trace their origin to some religious narratives of some sort. A case in point is that of the Yoruba people in Nigeria who refer to Olodumare as the creator of all, and they allude to other demigods who mediate between Olodumare and human beings (Oladipo 1998: 204). Similar narratives span through other African cultures. 
Does this justify the religious interpretation of cultures or the "religionising" of identity? Perhaps not! The opening remark of John Mbiti's African religions and philosophy - "The African is notoriously religious" (Mbiti 1969: 1) sheds light on the understanding of the religious nature of most African cultures. If most cultures are religious, why should Africans be notoriously religious? Oladipo (1998) attempts a response to this question when he argues that as opposed to an understanding of religion from the viewpoint of religious experiences, religion in an African is interpreted from an attitudinal point of view (Oladipo 1998: 201-202). This position is different for an understanding of religion as mere experience, in that there is also a dimension which calls for a physical religious disposition, which Oladipo refers to as "religious attitude". He defines religious attitude as "a response to that "thing' which is considered to be the ultimate reality and which, for that reason, is indestructible" (Oladipo 1998: 203). Religion as attitude implies that it permeates all facets of life. A good example is the demigod of farmers, Òrisà Oko, who is implored for a good harvest (Oladipo 1998: 206) and Sango, the demigod of thunder who is often called upon for retribution purposes. In most cases these beckonings on demigods are done through rituals.

In these rituals, religion is not conflated with culture as the source of identity, but is rather a dimension of it. If the rudimentary definition of culture as a total way of life is adopted, religion is not a total way of life of any given culture. It is only a facet of a larger world view. This does not rule out the fact that: "As a complex of symbols and as a cultural institution, religion claims in some form to provide answers to questions of ultimate meaning, questions about the nature and destiny of human beings. And religion, unlike comprehensive ideologies... seeks its answers in a transcendental realm, in an appeal to some supernatural power" (Davis 1994: 22). Religion only provides transcendental explanations to reality and this only serves to placate people in their desire for explanations. Even if religion can be said to play a significant role, it does not necessarily justify the claim that it is dominant, since it can be distinguished from other facets of life which have nothing to do with religion.

The question of differentiating religion from culture is not as easy as it seems. The question of what category religion belongs to cannot be left unaddressed. Before attempting this issue, I will nuance my understanding of African traditional religion. When I refer to African traditional religion in relation to culture, I mean that religion and culture have different modes of expression in the society. In Africa's diversity, there is a commonality which is connected to African experience and an appeal to a transcendental reality often referred to as God. Religion has a category of its own, which justifies my initial claim that religion is only a facet of culture. In fact, religious practices show that it is a plea to God to intervene in realities which cannot be "understood" by human beings. This is noticeable in the rituals and prayers that are carried out when people lose their beloved ones through death. Even if one is to argue that religion is to seek divine intervention which we do understand: 
joblessness or sickness, there is still a dilemma regarding the interpretation on how divine interventions are to be understood. At this point, I would like to draw from the movie, Matrix, to buttress the point I have been making. The aim is to juxtapose and then elaborate the difference between religion and culture. The intended motive remains the same: culture, as experience, is much more than religion.

\title{
RELIGIOUS MATRIX
}

The word Matrix derives from the movie of the same name, which astounds in action and makes astonishing use of special graphical effects. Since the first Matrix was first screened, philosophers over the years have acknowledged that the movie has some philosophical implications which point to modern and contemporary intellectual systems. Hubert Dreyfus and Stephen Dreyfus argue:

\begin{abstract}
What the phenomenologist can and should claim is that, in a Matrix world where bodies are in vats, the people whose brains are getting virtual reality inputs correlated with their action outputs, are nonetheless directly coping with perceived reality, and that that reality isn't experienced as inner. Even in the Matrix world, people directly relate to perceived chairs by sitting on them. Thus coping, even in the Matrix, is more direct than conceived of by any of the inner/outer views of the mind's relation to the external world that have been held from Descartes to Husserl. (Dreyfus and Dreyfus n.d.: 3)
\end{abstract}

The implication of Dreyfus and Dreyfus's argument to religion, which the movie Matrix and the sequel construe, is that it has had a numbing effect on humanities' conceptualisation of what constitutes reality. This point will be addressed as this paper proceeds. The movie shows that "the people who live in the Matrix have no other source of experience than what happens in the Matrix" (Dreyfus and Dreyfus n.d.: 3).

Dreyfus and Dreyfus go on to argue that: 'To understand what is wrong with living in the Matrix world we have to understand the source of the power of the Matrix illusion. Part of the power comes from the way the inputs and outputs from the computer are plugged directly in the brain's sensory motor-system. When we experience ourselves as acting in a certain way, say walking inside a house, the computer gives us the correlated experiences of seeing the interior' (Dreyfus and Dreyfus n.d.: 5). What this indicates is that even within the illusory world there is a sense in which, more than just a cognitive action, there is need for a pragmatic awareness of the Matrix; thus necessitating a correlation between the cognitive and the pragmatic within the Matrix. It is important at this point to reintroduce the idea of the soul which I hinted at in the paragraph above.

The religious Matrix can be likened to an 'idea' which people willingly or sometimes forcefully allow themselves to be connected to or enchanted by; an idea that presents an ethereal horizon as if it is reality which contains an ideal state of being. The acceptance of these ideal states of being often results in the creation of 
ideologies to further legitimise this ideal state. This is why "Religion sets criteria for judging what human beings imagine or make is good and worthwhile. It questions whether we are right to regard as valueless everything we have not made ourselves" (Davis 1994: 22). Over the years Boko Haram ${ }^{3}$ has been reported to carry out the bombing of schools, churches and mosques; the abducting of school girls in northern Nigeria; killings in Cameroon and Chad; and bomb blasts in Nairobi (Chothia 2015). Elsewhere on the continent a Sudanese woman was condemned to death by hanging for apostasy in marrying a Christian.

What one realises with religions today is that there is an obsession with the ethereal; a reality that justifies the Christian hymn ("This world is not my own") and the Islamic quest to make the world "the abode of Allah - dar Islam". A unique difference is, however, identified in the African traditional religion as there is great emphasis on the realities of the culture and this has often been the contextualised Matrix for relating with God. In most African cultures, especially in West Africa, when there is doubt about the credibility of a diviner, more credible diviners are sourced from neighbouring villages. This is not to defend African traditional religious forms of ritual killing(s). Perhaps instances like these are questionable and also require that Africans adopt fully the phenomenological understanding of religious beliefs.

With the advent of imported religions, I argue that Africans have not been able to live their identities and theorise themselves in a world where Africa's own contributions to cultural and social organisation have been denigrated or even ignored. The African traditional religions have been frequently devalued and only the authority of imported religions is seen to have significance. One of the questions this might provoke is, is religion a new form of Western colonialism? We must also wonder if religion is the suppression of an identity and the imposition of an ideology. It is no exaggeration that African traditional religions have been seen as culturally irrelevant by some if not most Africans, and imported religions are now so embedded in the psychology of Africans that most Africans have been lulled into acceptance thereof. "The human capacity to wonder - a capacity that is universal - may give rise to two different attitudes: one of superstitious leading to beliefs and presuppositions that can hardly be rationally and scientifically grounded; the other is rational leading to beliefs and explanations that can be grounded in reason" (Gyekye 2004: 29). Gyekye's (2004) use of the words 'superstitious', 'rational' and 'scientific' is a clear sign that he has bought into rhetoric and labels of imported Western religions. African traditional cultures have wondered and, arguably, the outcomes may not fall under the category of that which is 'rational and scientific', but it is not far removed from the experience of the people. African traditional cultures have survived many

3 Boko Haram is a pseudo name for a movement called, Jama'atul Ahlus Sunna Lid Da'awatis Jihad. The Boko Haram sect is Islamic and said to have links with Al Qaeda. The term Boko Haram has to do with their ideological framework rather than their identity. 
centuries because the outcomes of their wonder have not been detrimental to their existence.

Different from Gyekye's (2004) assertion, Davis (1994) argues that “Traditional religious people have a conventional identity. Their religious identity is tied to the fixed contents of a tradition, to its institutions and practices...Any substantial change in the normative content and rules of the tradition is experienced as a loss of identity and, consequently, is fiercely resisted" (Davis 1994: 141). Davis goes on to say that "History shows that such a conventional religious identity may flourish in a naïve fashion while simply ignoring the existence of other traditions and thus evading the reflection which a taking cognizance of their existence would provoke" (Davis 1994: 141). Davis's arguments are true, but some flaws can be spotted. Davis is right in positing that African traditional religious disposition is conventional because these traditions are considered to be sacred. However, as I argued in the early part of this article, African traditional culture is never reluctant in seeking solutions to problems by imploring or appropriating norms which are not unique to its customs. Imported religions have a tendency to suspend the experiential dimension of individuals; and it is a reality which needs to be subdued in order to be in touch with the actions in realities of the world, which provokes certain reactions.

Colonialism has had a role in effecting this reality in the imaginary of Africans. As Taylor argues: "It is held that since 1492 Europeans have projected an image of such people as somehow inferior, 'uncivilised,' and through the force of conquest have often been able to impose this image on the conquered" (Taylor 1994: 26). Everything that came with colonialism had the intent of civilising, eradicating the inferior image that was perceived in Africa and above all, creating a new culture and identity. Kwasi Wiredu's scenario of a Luo person in a Luo culture, with this no narrative or understanding of creation, is a good example to further illustrate this point. A Luo person was once asked: "Who made you?" After saying that he does not know, the missionary told him that a better response would be provided (Wiredu 1998: 34). Colonialists' intention must not be seen in a negative light alone, neither must it be analysed with an uncritical lens. Given the happening in some African countries, it is important to think of the role imported religions should have in the continent.

\section{RELIGIOUS MATRIXAND MULTIPLE MATRIX}

Identity has to do with the experience of a certain Matrix. It has to do with a certain awareness of one's "situatedness" as a starting point. This is where important questions arise: Who am I? What am I? It is significant to note that religion often creates a Matrix which can sometimes promote a new structure within society. This is not purely negative, as it can be said to have a unifying nature to it in that it creates a new collective purpose. However, there is a sense in which these new religious 
structures base their authenticity on a transcendental justification, which may not be accessible to those who do not adhere to their beliefs.

Such a structure would include the view of Menachem Begin, who once said: "Nobody has the right to tell me whether I can stay in Judea and Samaria, since this right is given to me by God and Father of Abraham, Isaac and Jacob" (quoted in Davis 1994: 112). Also would be included the self-ascribed nature of Christian and Muslim religious monopoly of validity. "The monological ideal seriously underestimates the place of the dialogical in human life. It wants to confine it as much as possible to the genesis" (Taylor 1994: 33). In most cases, the imported religious monologue, hegemony and strive for monopoly make human beings and their experiences expendable. Human experiences have not been of great significance in Africa's understanding of their identity, as little or no emphasis has been placed on the African experiences. If such experiences have been mentioned at all they have been distorted by religious obfuscating rhetoric which draws its authority from the supremacy of an imported religion. More and more in Africa one experiences a transborder religious relationship. A reality that has made people more interested in what is happening among the people whom they share the same religion with, rather than those they share the same experience with. African experiences sometimes fall prey to the superimposed hegemony of religious world views. What remains glaring is that religious [imported religious] experiences do not consider other experiences as that which is also part of their experience; the tendency is to control and redefine other people's experiences. This is not to say that religious views cannot be categorised under experience. The point I emphasise here is that shared religious world view has been prioritised when compared with other experiences. There is something fundamental in imported religion which cannot be separated from the cultural matrix in their origin and the cultural matrix in which they are received. This justifies the bond often promoted across borders.

As much as cultural Matrix, "what we mean by identity... who we are, where we're coming from" (Taylor 1994: 33) is considered important, it is equally important that our striving for multiple matrixes does not obliterate the consciousness of our cultural Matrix. As already highlighted, religion cannot be separated from its cultural Matrix. As Africans, gullible tendencies must not override our reflective impulse. As Armstrong recounts: "In all cultures, human beings have been driven by the same imperatives: to be intelligent, responsible, reasonable, loving and, if necessary, change. The very nature of humanity, therefore, demands that we transcend ourselves and our current perceptions and this principle indicates the presence of what has been called the divine in the very nature of serious human inquiry" (Armstrong 1993: 185).

The attempt to include the human inquiry has often resulted in a major lapse in the conception of religion. In fact, it raises a fundamental question as to how "the 
dignity of the individual as an absolute value be retained without a relation to the Absolute?" Davis goes on to "suggest that the individual is of unconditional worth, because at the deepest level the personal self is one with Absolute Reality" (Davis 1994: 151). To claim that the self has an absolute reality can actually plunge us back to the reality which further raises the question of the origin of this absolute reality. Then we are back to square one!

Amidst the religious differences which can be identified, the point which should take precedence in the midst of the diversity is the idea of recognition of the difference and the integration of imported religion to the cultural Matrix in which we find ourselves. This assertion does not rule out the fact that imported Matrix should not give reason to rethink our own Matrix. The point is that it should not make us, Africans, oblivious of our Matrix. Most Christians have talked about the whole idea of enculturation as a way of being in touch with how different African cultures can be incorporated into Christianity and vice versa. However, one realises that this has not really been in touch with the experiences of the people and consequently ignores the main part of the African identity.

Imported religions from the onset have engaged in a monologue and they have insisted on imposing this monologue on Africans, and Africans have unconsciously appropriated this monologue and ignored the significant of dialogue with experience. Taylor argues that "General recognition was built into the socially derived identity by virtue of the very fact that it was based on social categories that everyone took for granted. Yet inwardly derived, personal, original identity doesn't enjoy this recognition a priori - recognition has to be attained through exchange and the attempt to fail" (Taylor 1994: 34-35). This is an assertion which may also imply that "religious traditions do not have to be conceived as static and unchanging. Rather, they possess a temporality of their own, a rhythm which may be more fundamental than the time of the philosophers" (Rosemann 2007: 161).

\section{POLITICS OF RECOGNITION: A PHENOMENOLOGICAL UNIFYING MATRIX}

The onus is ours "The God of Jews, Christians and Muslims is a God who - in some sense - speaks. His Word is crucial in all three faiths. The Word of God has shaped the history of our culture. We have to decide whether the word 'God' has any meaning for us today" (Armstrong 1993: 16) as Africans. When we pledge allegiance to a particular religion, it is a commitment to a set of norms. It is important to know that:

... norms are not created out of nothing. They are formed out of the needs, interests and wants of actual human beings. The normative thus presupposes and builds upon the factual truths about human beings established in the cognitive sphere of culture; but the normative should be distinguished from the cognitive. Human beings come together in society, creating 
norms and embodying them in institutions through a process of social interaction. (Davis 1994: 27)

This calls for constructive possibilities as a good disposition for understanding the multiplicity inherent in experiences. The point here is that the point of departure must always be from the experience within which we are situated: '.. our thinking and philosophy... [must be] directed toward the redemption of our society' (Nkrumah 1998:81). It is only by thinking within our context that the contents of our reactions are positively informed. I guess it is equally important for the outside to pay attention to these experiences so as to better engage the experience of mission venues.

It is evident that over the years, religious ideas have been spilling into politics. "Religious beliefs are the changing, limited, culturally particular manifestation of religious faith. Therefore, in political argument, religious people must be prepared to see their religious beliefs challenged. They must refrain from using any weapons to advance their beliefs other than the force of better argument" (Davis 1994: 36). The question is, who determines the criteria for what a better argument entails? The nature of a better argument, I will argue, is one which is not ideological and does not claim essentialist and infallible attributes, such that are not disposed to the truths in other arguments. The significance we give to each other enables us to live together and respect epistemological diversities and experience as the foundation.

However, it is a misconception to let go of their prejudice or allow themselves to be subdued by others. Deep-seated political questions cannot be understood, unless individuals learn to subdue and transcend their individual inclinations, and open up to unlimited reality through engaging in diverse and unlimited responses to reality (Davis 1994: 36-37). This reality must not replace African realities, but it can challenge Africans in their situatedness. For Taylor (1994), the politics of recognition proceeds from the proposition that an ontological ethical notion of the Other as a relational identity, must not be ignored. The point here is that ontology, understood as the question about the meaning of being, is a reality that is unique to every human being. As such, there is a moral obligation, in fact an imperative, that individual experiences must be respected. The experiences which constitute the otherness of the Other, always inform individual uniqueness.

\section{CONCLUSION}

Africans have appropriated the notion that religion is typically essentialist in nature and in most cases not subjected to revision (Rosemann 2007: 171). An ideology that shows how "... Religion elevates the rhythm of nature to a symbolic level, conferring spiritual meaning upon it. This sublimation of natural time enables us to live in accordance with natural rhythms of summer and winter, life and death, and so forth, while also creating a distance from them - a space in which authentically human meaning can arise that transcends merely natural cycles" (Rosemann 2007: 178). 
The point here is that we have become more in touch with nature (experience) and the reason behind our experiences. This can be achieved if we return religion to its rightful source, which is experience.

Quoting Rabindranath Tagore's Man the artist, Martha Nussbaum recounts: “At a certain bend in the path of evolution man refused to remain a four-footed creature, and the position, which he made his body to assume, carried in it a permanent gesture of insubordination" (Nussbaum 2013: 82). The significance of imported religions should be to better help us be in touch with our experiences. To walk on four-feet when we have to and then not deter us from walking on two feet when we know it helps us see what we cannot see when on four feet. And our decisions must be influenced by our own experiences as Africans, for it is who we are and where we are coming from. A healthy mutual understanding of the contingencies that make us who we are, and the contingencies of the Matrix from which we are formed, should be given priority in Africa. It is only in understanding the contingency that makes us, that we realise that identity is not religion but origin.

As Taylor recounts: "Negate identity by forcing people into a homogeneous mould that is untrue to them" (Taylor 1994: 43). Like Neo in the movie Matrix, "We are led to expect that, in return for accepting everyday vulnerability and suffering, the people liberated by Neo [experience] will be reborn to a new and better life" (Dreyfus and Dreyfus n.d.: 7). Hence, "What's ultimately important to us, then, is not whether most of our beliefs are true or false, or whether we are brave enough to face a risky reality, but whether we are locked into a world of routine, standard activities or are free to transform the world and ourselves" (Dreyfus and Dreyfus n.d.: 11) and to focus on our experiences. We have given power to religion. We have to reclaim the power we have given to religion and channel it to experience, where our identity lies.

\section{REFERENCES}

Armstrong, K.1993. A history of God: The 4000 year quest of Judaism, Christianity and Islam. New York: Random House Publishing Group.

Awolalu J.O. 1976. What is African traditional religion? www.comparativereligions.com/uploads/ articlepdf/268.pdf (accessed 18 March 2016).

Chothia, F. 2015. Who is Boko Haram?. http://www.bbc.com/news/world-africa-13809501 (accessed 18 March 2016).

Davis, C. 1994. Religion and the making of society. Cambridge: Cambridge University Press.

Dennett, D.C. 2006. The spell: Religion as a natural phenomenon. New York: Penguin Groups.

Dreyfus, H. and Dreyfus, S. n.d. Existential phenomenology and the brave new world of the Matrix. http://users.manchester.edu/Facstaff/SSNaragon/Online/texts/201/Dreyfus, $\% 20$ Matrix.pdf (accessed 10 December 2014). 
Gyekye, K. 2004. Our human nature, our human values. In Beyond cultures: Perceiving a common humanity. Edited by K. Gyekye. Washington: Council for Research in Values and Philosophy, Ghana Academy of Arts and Science, p. 27-56.

Mbiti, J.S. 1969. African religions and philosophy. London: Heinemann.

Ramose, M.B. 1998. The philosophy of Ubuntu and Ubuntu as a philosophy. In The African philosophy reader. Edited by P.H. Coetzee and A.P.J. Roux. New York: Routledge, p. 230238.

Nussbaum, M.C. 2013. Political emotions: Why love matters for justice. Cambridge: Harvard University Press.

Okolo. C.B. 1998. Self as a person in African philosophy. In The African philosophy reader. Edited by P.H. Coetzee and A.P.J. Roux. New York: Routledge, p. 209-215.

Oladipo, O. 1998. Metaphysics, religion, and Yoruba traditional thought. In The African philosophy reader. Edited by P.H. Coetzee and A.P.J. Roux. New York: Routledge, p. 200-208.

Rosemann, P.W. 2007. Truth, time, religion. In Belief and metaphysics. Edited by P.M. Candler and C. Cunningham. London: SCM Press.

Taylor, C. 1994. The politics of recognition, In Multiculturalism. Edited by A. Gutmann. Chichester: Princeton University Press.

Toft, M.D. 2011. Religion, rationality, and violence. New York: Columbia University Press.

Wiredu, K.1998. On decolonizing African religions. In The African philosophy reader. Edited by P.H. Coetzee and A.P.J. Roux. New York: Routledge, p. 20-34. 